\title{
FORMULASI UNDANG-UNDANG BADAN HUKUM PENDIDIKAN (Pencarian Bentuk dan Batasan Pengaturan)
}

\author{
Suharizal \\ Fakultas Hukum Universitas Andalas Padang \\ E-mail : aripdg@yahoo.com
}

\begin{abstract}
Constitution court of justice verdict Number 11-14-21-126 and 136/ PUU-VII/ 2009 that read date 31 march 2010 then, has juridical implication very vast towards education system in indonesia. Those implication not only limit the act number 9 year 2009 concerning education corporate body, but it implicated to vast towards higher education management as a whole. This article means to study the decision and trace the will of constitution court of justice in the form of "education corporate body" that constitutional.
\end{abstract}

Keyword; constitution, education, justice verdict

\begin{abstract}
Abstrak
Putusan Mahkamah Konstitusi Nomor 11-14-21-126 dan 136/ PUU-VII/ 2009 yang dibacakan tanggal 31 Maret 2010 lalu, memiliki implikasi yuridis yang sangat luas terhadap sistem pendidikan di Indonesia. Implikasi ini bukan hanya membatasi Undang-Undang Nomor 9 tahun 2009 tentang Badan Hukum Pendidikan, tetapi berimplikasi besar terhadap manajemen pendidikan tinggi secara keseluruhan. artikel ini dimaksudkan untuk mempelajari putusan dan jejak dari keinginan pengadilan konstitusi mengenai bentuk "Badan Hukum Pendidikan "yang konstitusional.
\end{abstract}

Kata kunci; konstitusi, pendidikan, putusan pengadilan

\section{Pendahuluan}

Rabu, 31 Maret 2010, Mahkamah Konstitusi (MK) dalam perkara Permohonan Pengujian Undang-Undang Nomor 20 Tahun 2003 tentang Sistem Pendidikan Nasional dan Undang-Undang Nomor 9 Tahun 2009 tentang Badan Hukum Pendidikan terhadap UUD 1945, membatalkan UU Nomor 9 Tahun 2009. Sidang MK digelar untuk mengakomodasi uji materiil yang diajukan oleh para pemohon yang terdiri dari elemen mahasiswa, orang tua siswa, dan badan hukum yang bergerak di bidang pendidikan, serta yayasan pendidikan swasta.

Ada lima kelompok yang mendaftarkan permohonan uji materi terhadap UU BHP ini. Kelompok pertama terdiri dari sejumlah yayasan yang bergabung dalam Asosiasi Badan Penyelenggara Perguruan Tinggi Swasta Indonesia (ABPPTSI) dan Yayasan Pembina Lembaga Pendidikan Persatuan Guru Republik Indonesia (YPLP-PGRI), Yayasan Pesantren Islam Al-Azhar,
Yayasan Trisakti, Yayasan Pendidikan dan Pembina Universitas Pancasila, Yayasan Pendidikan Mardi Yuana, YPTK Satya Wacana dan lainnya dengan kuasa pemohon Dr. Luhut MP Pangaribuan. Kelompok kedua, dari Yayasan Sarjana Wiyata Tamansiswa, Sentra Advokasi Untuk Hak Pendidikan Rakyat (SaHdaR) dan lainnya, dengan kuasa pemohon Taufik Basari, SH. Kelompok ketiga diajukan Aep Saepudin, Kristiono dan kawan-kawan, dengan kuasa pemohon Emir Zullarwan Pohan, SH. Kelompok keempat, Aminuddin Maruf dengan kuasa pemohon Saleh, SH. Kelompok kelima, dengan pemohon Yura Pratama Yudhistira, Yayasan Sarjana Wiyata Tamansiswa dan lainnya, dengan kuasa hukum Taufik Basari, SH.

Putusan MK Nomor 11-14-21-126 dan 136/ PUU-VII/ 2009 tersebut, apabila diperhatikan paling tidak terdapat lima alasan MK menggugurkan eksistensi BHP. Pertama, UU BHP mempunyai banyak kelemahan baik secara 
yuridis, kejelasan maksud dan keselarasan dengan UU lain. Kedua, UU BHP mempunyai asumsi penyelenggara pendidikan di Indonesia mempunyai kemampuan sama. Tapi, realitasnya kesamaan perguruan tinggi negeri (PTN) tak berarti semua PTN mempunyai kesamaan yang sama. Ketiga, pemberian otonomi kepada PTN akan berakibat beragam. Karena lebih banyak PTN yang tidak mampu menghimpun dana karena terbatasnya pasar usaha di tiap daerah. Hal ini akan menyebabkan terganggunya penyelenggaraan pendidikan. Keempat, UU BHP tidak menjamin tercapainya tuj uan pendidikan nasional dan menimbulkan kepastian hukum. Kelima, prinsip nirlaba tak hanya bisa diterapkan dalam BHP tapi juga dalam bentuk badan hukum lainnya. MK dalam putusan a quo menyatakan bahwa perubahan UUD 1945 menempatkan pendidikan sebagai barang publik (public goods) dan bukan barang privat (private goods).

Selain memutus bahwa UU Nomor 9 Tahun 2009 bertentangan dengan UUD 1945, MK juga memutus bahwa Pasal 6 ayat (2), Pasal 12 ayat (1) huruf $c$ dan Penjelasan Pasal 53 ayat (1) UU Nomor 20 Tahun 2003 tidak mempunyai kekuatan hukum mengikat. Namun sesungguhnya MK tidak "mencabut" embrio Badan Hukum Pendidikan yang terdapat dalam Pasal 53 ayat (1) UU Nomor 20 Tahun 2003. Dalam amar putusannya MK menyatakan;

Pasal 53 ayat (1) Undang-Undang Nomor 20 Tahun 2003 tentang Sistem Pendidikan Nasional (Lembaran Negara Republik Indonesia Tahun 2003 Nomor 78, Tambahan Lembaran Negara Republik Indonesia Nomor 4301) konstitusional sepanjang frasa "badan hukum pendidikan" dimaknai sebagai sebutan fungsi penyelenggara pendidikan dan bukan sebagai bentuk badan hukum tertentu; ${ }^{1}$

Pasca-keluarnya Putusan MK Nomor 1114-21-126 dan 136/PUU-VII/2009, tanggal 31 Maret 2010 proses legislasi pembentukan peraturan-perundangan yang mengatur makna "Badan Hukum Pendidikan" yang bersesuai dengan putusan MK tersebut adalah upaya

\footnotetext{
1 Putusan Mahkamah Konstitusi Nomor 11-14-21-126 dan 136/ PUU-VII/ 2009, tanggal 31 Maret 2010, hlm. 401.
}

hukum yang bisa dilakukan. Dari uraian di atas, paling tidak terdapat tiga permasalah penting yang akan dibahas dalam tulisan ini, yakni Pertama, apakah alasan bagi Mahkamah Konstitusi untuk membatalkan Undang-Undang Nomor 9 Tahun 2009 tentang Badan Hukum Pendidikan melalui Putusan MK Nomor 136/ PUU-VII/2009, tanggal 31 Maret 2010; Kedua, Bagaimanakah sesungguhnya formulasi dari Badan Hukum Pendidikan yang konstitusional; Ketiga, langkah apakah yang dapat ditembuh pasca terbitnya Putusan MK Nomor 136/ PUU$\mathrm{VII} / 2009$.

Sebelum menjelaskan beberapa tafsiran atas makna "Badan Hukum Pendidikan" yang terdapat dalam Pasal 53 ayat (1) UU Nomor 20 Tahun 2003, perlu dijelaskan tentang kewenangan MK dan beberapa langkah yuridis Pascakeluarnya Putusan MK tersebut. Langkah yuridis ini adalah tindakan legislasi yang amat mendesak (emergency law) untuk menghindari terjadinya persoalan-persoalan hukum, khususnya semua regulasi yang dibentuk yang mengacu kepada UU Nomor 9 Tahun 2009.

\section{Pembahasan \\ Kewenangan MK}

Perubahan UUD 1945 dalam bidang kekuasaan kehakiman (Bab IX) amandemen ketiga, memberikan kewenangan yang sangat luas terhadap kekuasaan kehakiman untuk melakukan koreksi terhadap segala perbuatan atas pelanggaran hukum yang terjadi dalam masyarakat, melakukan pengujian terhadap peraturan perundang-undangan yang berada dibawah undang-undang, pengujian undang-undang terhadap UUD dan memeriksa sengketa politik. ${ }^{2}$

Dalam rangka melaksanakan amanat amandemen konstitusi tentang pembentukan Mahkamah Konstitusi, pemerintah bersama DPR

\footnotetext{
2 Implikasi dari pembentukan norma baru tentang kekuasaan kehakiman sebagaimana diatur dalam Pasal 24 UUD 1945, maka dibuatlah dan ditetapkannya beberapa undang-undang di bidang kehakiman yaitu antara lain: UU No 4 tahun 2004 tentang Kekuasaan Kehakiman, UU No 5 tahun 2005 tentang Mahkamah Agung, UU No. 24 tahun 2003 tentang Mahkamah Konstitusi, UU No. 8 tahun 2004 tentang Peradilan Umum, UU No. 9 tahun 2004 tentang Peradilan Tata Usaha Negara, UU No. 7 tahun 1989 tentang Peradilan Agama, UU No. 31 tahun 1997 tentang Peradilan Militer.
} 
membahas Rancangan Undang-Undang tentang Mahkamah Konstitusi. Pada Perubahan Keempat UUD 1945 ditetapkan Pasal III Aturan Peralihan UUD 1945 yang menegaskan batas waktu paling akhir pembentukan Mahkamah Konstitusi pada 17 Agustus 2003. Sebelum dibentuk, segala kewenangan Mahkamah Konstitusi dilakukan Mahkamah Agung. Pada tanggal 13 Agustus 2003, sebelum MK terbentuk dengan ditetapkannya UU No. 24 Tahun 2003, berdasarkan Aturan Pera-lihan UUD 1945, kewenangan MK masih dilakukan oleh MA sebagai MK sementara atau transisi. Terdapat 14 permohonan pengujian undang-undang yang diajukan sebelum MK resmi terbentuk, akan tetapi sampai dengan dialihkan kepada MK belum pernah diputus oleh MA yang kemudian dialihkan kepada MK, sehingga sejak awal MK berdiri telah harus menyelesaikan 14 permohonan pengujian UU. Adapun secara keseluruhan, pada 2003 MK menerima 24 permohonan yang semuanya perkara pengujian undang-undang. Pada tahun tersebut, yang tersisa waktu 4 bulan, telah diputus 4 perkara, 3 dinyatakan tidak dapat diterima dan 1 ditarik kembali. Terdapat 16 UU yang dimohonkan untuk diuj i konstitusionalitasnya

Setelah dilakukan pembahasan, akhirnya RUU usulan DPR tersebut dapat disepakati bersama antara pemerintah bersama DPR dan disahkan dalam sidang paripurna DPR pada tanggal 13 Agustus 2003. Pada hari itu juga UU tentang MK diundangkan oleh Presiden menjadi UU Nomor 24 Tahun 2003 tentang Mahkamah Konstitusi. $^{3}$

Pada tanggal 15 Agustus 2003, sembilan Hakim Konstitusi pertama diangkat dengan Keputusan Presiden Nomor 147/M/Tahun 2003 yang dilanjutkan dengan pengucapan sumpah di Istana Negara pada 16 Agustus 2003 yang disaksikan Presiden Megawati Soekarnoputri. ${ }^{4}$ Setelah mengucapkan sumpah jabatannya sebagai Hakim Konstitusi, para Hakim Konstitusi langsung bekerja menunaikan tugas konstitusi-

\footnotetext{
3 Kemudian dimuat dalam Lembaran Negara Republik Indonesia Tahun 2003 Nomor 98, dan Tambahan Lembaran Negara Republik Indonesia Nomor 4316.

4 Abdul Mukhtie Fadjar, 2006, Hukum Konstitusi dan Mahkamah Konstitusi, Jakarta: Sekjen Dan Kepaniteraan Mahkamah Konstitusi RI, hIm. 112-113.
}

onalnya sebagaimana tercantum dalam UUD 1945 dan Undang-Undang Mahkamah Konstitusi.

Pada saat itu, Indonesia merupakan negara ke-78 yang membentuk Mahkamah Konstitusi. Tanggal 13 Agustus 2003 sebagai tanggal ditetapkan dan disahkannya Undang-Undang Nomor 24 Tahun 2003 inilah yang disepakati menjadi hari kelahiran Mahkamah Konstitusi. Setelah penetapan undang-undang tersebut, dilanjutkan dengan rekrutmen Hakim Konstitusi oleh setiap lembaga pengusul, yaitu DPR, Presiden, dan MA. Setelah melalui tahapan seleksi sesuai mekanisme yang berlaku pada masing-masing lembaga tersebut, DPR, Presiden, dan MA menetapkan tiga calon Hakim Konstitusi yang selanjutnya diajukan kepada Presiden untuk ditetapkan sebagai Hakim Konstitusi. DPR mengajukan nama-nama Prof. Dr. Jimly Asshiddiqie, S.H., Letjen TNI (Purn) H. Achmad Roestandi, S.H., dan I Gede Dewa Palguna, S.H., M.H. Presiden mengajukan nama Prof. H. Ahmad Syari-fuddin Natabaya, S.H., LL.M., Prof. H. Abdul Mukhtie Fadjar, S.H., M.S., dan Dr. Harjono, S.H., M.C.L. Adapun MA mengajukan nama Dr. H. Mohamad Laica Marzuki, S.H., Maruarar Siahaan, S.H., dan Soedarsono, S.H. Masa jabatan Hakim Kons-titusi adalah 5 (lima) tahun dan dapat dipilih kembali hanya untuk 1 (satu) kali masa jabatan berikutnya.

Ketua Mahkamah Konstitusi Moh. Mahfud MD, menjelaskan bahwa Mahkamah Konstitusi (MK) dibentuk pada tahun 2003 karena adanya kebutuhan untuk menjawab beberapa persoalan hukum di negeri ini yang sebelumnya menemui jalan buntu. Persoalan-persoalan hukum di masa lalu itu tercermin dalam kewenangan dan kewajiban yang dimiliki MK, yaitu menguji konstitusionalitas undang-undang, mengadili sengketa kewenangan lembaga negara, mengadili sengketa hasil pemilihan umum, memutus pembubaran partai politik, dan memutus perkara impeachment presiden. Sebagai lembaga negara produk reformasi, MK menjadi tumpuan ekspektasi masyarakat yang menginginkan terjadinya perbaikan dalam bidang penegakan hukum. Sejauh ini MK telah merespons harapan 
publik tersebut melalui proses peradilan yang bersih dan putusan yang menjunjung tinggi prinsip keadilan. ${ }^{5}$

Bila ditelusuri lebih jauh, pembentukan Mahkamah Konstitusi juga didorong oleh beberapa alasan mendasar dan praktek ketatanegaraan yang pernah berlaku. Pertama, sebagai konsekuensi dari perwujudan negara hukum yang demokratis dan negara demokrasi yang berdasarkan hukum. Kenyataan menunjukkan bahwa suatu keputusan yang dicapai dengan demokratis tidak selalu sesuai dengan ketentuan Undang-Undang Dasar yang berlaku sebagai hukum tertinggi. Oleh karena itu, di perlukan suatu lembaga yang berwenang menguj i konstitusionalitas undang-undang. ${ }^{6}$

Kedua, pasca Perubahan Kedua dan Perubahan Ketiga, UUD 1945 telah mengubah hubungan kekuasaan secara besar-besaran dengan menganut sistem pemisahan kekuasaan (separation of powers) berdasarkan prinsip checks and balances. Bertambahnya jumlah lembaga negara serta bertambahnya ketentuan kelembagaan negara menyebabkan potensi sengketa antar-lembaga negara menjadi semakin banyak. Sementara itu telah terjadi perubahan paradigma dari supremasi MPR kepada supremasi konstitusi, sehingga tidak ada lagi lembaga tertinggi negara pemegang kekuasaan tertinggi yang berwenang menyelesaikan sengketa antar lembaga negara. Oleh karena itu, diperlukan lembaga tersendiri untuk menyelesaikan sengketa tersebut. ${ }^{7}$

Ketiga, kasus nyata yang terjadi di Indonesia, yaitu pemakzulan (impeachment) Presiden K.H. Abdurrahman Wahid dari kursi kepresidenannya oleh MPR pada Sidang Istimewa MPR Tahun 2001, yang mengilhami tercetusnya pemikiran untuk mencari jalan keluar mekanisme hukum yang digunakan dalam proses

5 Mahfud MD, 2009, Enam Tahun Mengawal Konstitusi dan Demokrasi; Gambaran Singkat Pelaksanaan Tugas Mahkamah Konstitusi 2003-2009, J akarta: Sekretariat J enderal dan Kepaniteraan MK, hlm. vii.

6 S.F. Marbun, 2007, Nagara Hukum dan Kekuasaan, J urnal Hukum lus Quia lustum, No. 9 Vol 4, hlm. 9.

7 Abdul Rasyid Thalib, 2006, Wewenang Mahkamah Konstitusi dan Implikasinya dalam Sistem Ketatanegaraan Republik Indonesia, Bandung: Citra Adityia Bakti, hlm. 153 pemberhentian Presiden dan/atau Wakil Presiden tidak sematamata didasarkan alasan politis semata dan oleh lembaga politik saja. ${ }^{8}$

Mahkamah Konstitusi merupakan salah satu pelaku kekuasaan kehakiman selain Mahkamah Agung. Kekuasaan kehakiman adalah kekuasaan yang merdeka untuk menyelenggarakan peradilan guna menegakkan hukum dan keadilan. Dengan demikian, MK merupakan suatu lembaga peradilan, sebagai cabang kekuasaan yudikatif, yang mengadili perkaraperkara tertentu yang menjadi kewenangannya yang diberikan berdasarkan ketentuan UUD 1945. Berdasarkan Pasal 24C ayat (1) UUD 1945 yang ditegaskan kembali dalam Pasal 10 ayat (1) huruf a sampai dengan d UU 24/2003 tentang Mahkamah Konstitusi, kewenangan MK adalah menguji undangundang terhadap UUD 1945; memutus sengketa kewenangan lembaga negara yang kewenangannya diberikan oleh UUD 1945; memutus pembubaran partai politik; dan memutus perselisihan tentang hasil pemilihan umum. $^{9}$

Apabila dibaca bagian "mengingat" dari UU Nomor 24 Tahun 2003, paling tidak terdapat 3 (tiga) alasan pembentukan UU Nomor 24 Tahun 2003, yakni pertama, bahwa Negara Kesatuan Republik Indonesia merupakan negara hukum yang berdasarkan Pancasila dan UndangUndang Dasar Negara Republik Indonesia Tahun 1945, bertujuan untuk mewujudkan tata kehidupan bangsa dan negara yang tertib, bersih, makmur, dan berkeadilan; kedua, bahwa Mahkamah Konstitusi sebagai salah satu pelaku kekuasaan kehakiman mempunyai peranan penting dalam usaha menegakkan konstitusi dan prinsip negara hukum sesuai dengan tugas dan wewenangnya sebagaimana ditentukan dalam

8 Mahkamah Konstitusi RI, Enam Tahun...op-cit, hlm. 5-6.

9 Hingga saat ini, MK telah menjalankan dan menangani tiga macam perkara yang menjadi kewenangannya, yaitu menguji undang-undang terhadap UUD 1945; memutus sengketa kewenangan lembaga negara yang kewenangannya diberikan oleh UUD 1945; dan memutus perselisihan tentang hasil pemilihan umum. Mahkamah belum pernah memutus pembubaran partai politik dan memberikan keputusan atas pendapat DPR bahwa Presiden dan/atau Wakil Presiden telah melakukan pelanggaran hukum, atau perbuatan tercela, atau tidak memenuhi syarat sebagai Presiden dan/atau Wakil Presiden sebagaimana dimaksud dalam UUD 1945 karena belum pernah ada permohonan perkara tersebut. 
Undang-Undang Dasar Negara Republik Indonesia Tahun 1945; dan ketiga, bahwa berdasarkan ketentuan Pasal 24C ayat (6) UndangUndang Dasar Negara Republik Indonesia Tahun 1945 perlu mengatur tentang pengangkatan dan pemberhentian hakim konstitusi, hukum acara, dan ketentuan lainnya tentang Mahkamah Konstitusi;

Berdasarkan perkara antara 2003 sampai 23 Juli 2009, Mahkamah Konstitusi telah mengabulkan sejumlah 92 perkara atau sekitar $25,77 \%$ menolak sejumlah 132 perkara atau sekitar 36,97\% tidak dapat diterima sejumlah 83 perkara atau sekitar 23,25\% serta ketetapan penarikan kembali sejumlah 24 perkara atau sekitar $6,72 \%$ dan 4 putusan sela atau sekitar $1,12 \%$ Sehingga total yang diputus adalah 335 perkara dan terdapat 22 perkara yang masih dalam proses persidangan. ${ }^{10}$ Tentang jumlah dan presentasi putusan Mahkamah Konstitusi dari tahun 2003 sampai 2009 dapat dilihat pada tabel di bawah ini.

Berdasarkan empat wewenang dan satu kewajiban yang dimiliki Mahkamah Konstitusi sebagaimana diatur dalam UUD 1945 dan UU

Tabel 1.

Perbandingan J umlah dan Persentase Putusan 2003-J uli 2009

\begin{tabular}{|c|c|c|c|c|c|c|}
\hline Tahun & Registrasi & $\begin{array}{c}\text { Sisa } \\
\text { Perkara }\end{array}$ & $\begin{array}{c}\text { Perkara yang } \\
\text { ditangani } \\
\text { (b+c) }\end{array}$ & $\begin{array}{c}\text { Perkara } \\
\text { diputus }\end{array}$ & \multicolumn{2}{|c|}{ Persentase (\%) } \\
\hline $\mathbf{2 0 0 3}$ & 24 & - & 24 & 4 & 16.7 & 83,3 \\
\hline $\mathbf{2 0 0 4}$ & 73 & 20 & 93 & 82 & 88.2 & 11,8 \\
\hline $\mathbf{2 0 0 5}$ & 26 & 11 & 37 & 27 & 73.0 & 27.0 \\
\hline $\mathbf{2 0 0 6}$ & 31 & 10 & 41 & 32 & 78.0 & 22.0 \\
\hline $\mathbf{2 0 0 7}$ & 32 & 9 & 41 & 29 & 70.7 & 29.3 \\
\hline $\mathbf{2 0 0 8}$ & 66 & 12 & 78 & 56 & 72.7 & 27.3 \\
\hline $\mathbf{2 0 0 9}$ & 105 & 22 & 127 & 105 & 82,68 & 17,32 \\
\hline
\end{tabular}

Sumber: Mahkamah Konstitusi ${ }^{11}$

Nomor 24 Tahun 2003, maka dapat dikatakan Mahkamah Konstitusi merupakan pengawal konstitusi (the guardian of the constitution). Hal tersebut akan membawa sebuah konse-

\footnotetext{
10 Mahkamah Konstitusi RI, Enam Tahun ... op-cit, hlm. 18.

11 Mahkamah Konstitusi, 2009, Enam Tahun Mengawal Konstitusi Dan Demokrasi; Gambaran Singkat Pelaksanaan Tugas Mahkamah Konstitusi 2003-2009, J akarta: Sekretariat J enderal dan Kepaniteraan MK, hlm. 21.
}

kuensi MK berfungsi sebagai penafsir konstitusi (the sole interpreter of the constitution). Konstitusi sebagai hukum tertinggi mengatur penyelenggaraan negara berdasarkan prinsip demokrasi dan salah satu fungsi konstitusi adalah melindungi hak asasi manusia yang dijamin dalam konstitusi, sehingga menjadi hak konstitusional warga negara. Karena itu, sesungguhnya Mahkamah Konstitusi juga berfungsi sebagai pengawal demokrasi (the guardian of the democracy), pelindung hak konstitusional warga negara (the protector of the citizen's constitutional rights) dan pelindung HAM (the protector of human rights).

David Held memberikan konsepsi hubungan antara demokrasi, negara dan kebutuhan konstitusionalnya di mana ketiganya menjadi satu kesatuan sistemik dalam rangka memperkuat hak dan kewajiban dalam hukum publik yang demokratis. Held berpendapat, "state powers and institutions must be constitute and circumscribed by the requirement to enact this law, if the operation of democratic life is to be suitably restricted and framed". ${ }^{12}$

\section{Langkah yuridis Pasca-keluarnya Putusan MK}

Peraturan perundangan, baik dalam bentuk Peraturan Pemerintah (PP) ataupun dalam bentuk Peraturan Menteri (PP) yang dibentuk dan mengacu kepada UU Nomor 9 Tahun 2009, atau dengan kata lain, semua peraturan pelaksanaan dari UU Nomor 9 Tahun 2009 yang menempatkan UU Nomor 9 Tahun 2009 dalam konsiderasi "mengingat" harus direvisi (terbatas) atau bahkan dicabut. Baik BHPP, BHPD ataupun $\mathrm{BHPM}^{13}$ yang dibentuk dengan mengacu kepada UU Nomor 9 Tahun 2009 harus dicabut

12 David Held, 1995, Democracy and the Global Order: From the Modern State to Cosmopolitan Governance, Standford:Stanford University Press, hlm. 157.

13 Pasal 1 angka 2, 3, dan 4 UU Nomor 9 Tahun 2009; "Badan Hukum Pendidikan Pemerintah yang selanjutnya disebut BHPP adalah badan hukum pendidikan yang didirikan oleh Pemerintah. Badan Hukum Pendidikan Pemerintah Daerah yang selanjutnya disebut BHPPD adalah badan hukum pendidikan yang didirikan oleh pemerintah daerah. Badan Hukum Pendidikan Masyarakat yang selanjutnya disebut BHPM adalah badan hukum pendidikan yang didirikan oleh masyarakat." 
atau diadakan revisi terbatas. ${ }^{14}$ Sebagai contoh misalnya Peraturan Pemerintah Nomor $17 \mathrm{Ta}$ hun 2010 tentang Pengelolaan dan Penyelenggaraan Pendidikan, dan Peraturan Pemerintah Nomor 38 Tahun 2010 Tentang Badan Hukum Pendidikan Pemerintah Universitas Pertahanan Indonesia.

PP Nomor 17 Tahun 2010 tentang PengeIolaan dan Penyelengg-araan Pendidikan mengatur secara khusus menyangkut Perguruan Tinggi sebagai badan hukum. Walaupun PP Nomor 17 Tahun 2010 tidak merujuk kepada UU Nomor 19 Tahun 2009, namun secara materi bertentangan dengan tafsiran badan hukum pendidikan sebagaimana dimaksud oleh hakim MK dalam dua putusan, yakni; putusan Nomor 021/PUUIV/ 2006 pada 22 Februari 2007, dan Putusan MK Nomor 11-14-21-126 dan 136/ PUUVII/ 2009 tanggal 31 Maret 2010. sehingga PP Nomor 17 Tahun 2010 menjadi bagian yang harus direvisi. ${ }^{15}$

Kemudian, PP Nomor 38 Tahun 2010 harus dicabut pembentukkan PP ini merupakan pendelegasian dari UU Nomo 19 Tahun 2009. Dalam konsideran "mengingat" PP Nomor 38 Tahun 2010 mencantumkan UU nomor 39 Tahun 2009. Pasal 1 angka 1 PP tersebut berbunyi; "Badan Hukum Pendidikan Pemerintah Universitas Pertahanan Indonesia yang selanjutnya disebut BHPP UNHAN adalah badan hukum pendidikan yang didirikan oleh Pemerintah yang menyelenggarakan pendidikan tinggi ilmu pertahanan".

BHMN (Badan Hukum Milik Negara) seperti Universitas Indonesia, Institut Pertanian Bogor, Universitas Gajah Mada, Institut Tek-

\footnotetext{
${ }^{14}$ Pasal 7 (1) UU Nomor 9 Tahun 2009; BHPP didirikan oleh Pemerintah dengan peraturan pemerintah atas usul Menteri. Pasal 7 (2) UU Nomor 9 Tahun 2009; BHPPD didirikan oleh pemerintah daerah dengan peraturan gubernur atau peraturan bupati/ walikota. Pasal 7 (3) UU Nomor 9 Tahun 2009; BHPM didirikan oleh masyarakat dengan akta notaris yang disahkan oleh Menteri.

15 Pasal 221 Peraturan Pemerintah Nomor 17 Tahun 2010 tentang Pengelolaan dan Penyelenggaraan Pendidikan mengatur "Pada saat Peraturan Pemerintah ini mulai berlaku: i. Peraturan Pemerintah Nomor 61 Tahun 1999 tentang Penetapan Perguruan Tinggi Negeri sebagai Badan Hukum (Lembaran Negara Republik Indonesia Tahun 1999 Nomor 116, Tambahan Lembaran Negara Republik Indonesia Nomor 3860); dicabut dan dinyatakan tidak berlaku".
}

nologi Bandung yang dibentuk sebelum UU Nomor 20 Tahun 2003 dan UU Nomor 9 Tahun 2009, keberadaannya tetap diakui sebagai Perguruan Tinggi Negeri. Demikian pula BHMN yang dibentuk dengan konsideran UU UU Nomor 20 Tahun 2003 seperti Universitas Pendidikan Indonesia, Universitas Sumatera Utara dan Universitas Airlangga tetap diakui keberadaannya. Namun kesemua BHMN tersebut perlu merevisi Anggaran Dasar masing-masing sesuai dengan Putusan MK Nomor 11-14-21-126 dan 136/ PUUVII/ 2009.

\section{Tafsiran Yuridis "Badan Hukum Pendidikan"}

Pembentukkan sebuah Badan Hukum Pendidikan adalah sebuah keharusan dan amanat dari Pasal 53 (4) UU Nomor 20 Tahun 2003 yang menentukan bahwa Ketentuan tentang badan hukum pendidikan diatur dengan Undangundang tersendiri. Pasal 53 (4) tidak menjadi bagian yang dibatalkan dalam Putusan MK Nomor 11-14-21-126 dan 136/ PUU-VII/ 2009.

Pasal 53 ayat (1) UU Sisdiknas tentang BHP menjadi ratio legis lahirnya Putusan MK Nomor 11-14-21-126 dan 136/ PUU-VII/2009. UU Nomor 9 Tahun 2009 yang disusun atas dasar pemahaman "Badan Hukum Pendidikan" versi penjelasan Pasal 53 ayat (1) yang memahami "Badan Hukum Pendidikan" sebagai badan hukum publik atau badan hukum yang menyelenggarakan pendidikan, dibatalkan. Pasal 53 Ayat (1) menyebutkan, "Penyelenggara dan/ atau satuan pendidikan formal yang didirikan pemerintah atau masyarakat berbentuk badan hukum pendidikan. Menurut MK, istilah badan hukum pendidikan itu bukanlah nama dan bentuk badan hukum tertentu.

MK dalam putusan a quo menyatakan bahwa "Badan Hukum Pendidikan" harus dimaknai sebagai fungsi penyelenggaraan pendidikan. J auh sebelum Putusan MK Nomor 1114-21-126 dan 136/PUU-VII/2009 dibaca, sesungguhnya MK melalui putusan Nomor 021/ PUUIV/ 2006 pada 22 Februari 2007 sudah menafsiran 4 (empat) aspek penting yang dimaksud dengan "Badan Hukum Pendidikan" sebagai amanat dari Pasal 53 (1) junto Pasal 53 (4) UU Nomor 20 Tahun 2003, yakni Pertama, 
Aspek fungsi negara untuk mencerdaskan kehidupan bangsa (Alinea Keempat Pembukaan), kewajiban negara dan pemerintah dalam bidang pendidikan sebagaimana ditentukan Pasal 31 ayat (2), ayat (3), ayat (4), dan ayat (5), serta hak dan kewajiban warga negara dalam bidang pendidikan sebagaimana ditentukan oleh Pasal 31 ayat (1) dan ayat (2), Pasal $28 \mathrm{C}$ ayat dan ayat (2), serta Pasal 28 ayat (1) (sic.) UUD 1945; Kedua, Aspek filosofis yakni mengenai cita-cita untuk membangun sistem pendidikan nasional yang berkualitas dan bermakna bagi kehidupan bangsa, aspek sosiologis yakni realitas mengenai penyelenggaraan pendidikan yang sudah ada termasuk yang diselenggarakan oleh berbagai yayasan, perkumpulan, dan sebagainya, serta aspek yuridis yakni tidak menimbulkan pertentangan dengan peraturan perundang-undangan lainnya yang terkait dengan badan hukum; Ketiga, Aspek pengaturan mengenai badan hukum pendidikan dalam undang-undang dimaksud haruslah merupakan implementasi tanggung jawab negara dan tidak dimaksudkan untuk mengurangi atau menghindar dari kewajiban konstitusional negara di bidang pendidikan, sehingga tidak memberatkan masyarakat dan/atau peserta didik; Keempat, Aspek aspirasi masyarakat harus mendapat perhatian di dalam pembentukan undang-undang mengenai badan hukum pendidikan, agar tidak menimbulkan kekacauan dan permasalahan baru dalam dunia pendidikan di Indonesia." 16

Di samping keempat aspek di atas, posisi pengelolaan kekayaan negara menjadi bagian tepenting dari menerjemahkan "Badan Hukum Pendidikan" sebagaimana diamanatkan dalam

\footnotetext{
${ }^{16}$ Putusan Nomor 021/ PUUIV/ 2006 pada 22 Februari 2007. $\mathrm{hlm}$. 134-135. Dalam Putusan MK Nomor 11-14-21-126 dan 136/ PUU-VII/ 2009 tanggal 31 Maret 2010 halaman 388, MK menyatakan; "Menimbang bahwa berdasarkan uraian di atas Mahkamah berpendapat bahwa UU BHP yang menyeragamkan bentuk hukum badan hukum pendidikan yang diselenggarakan oleh masyarakat (BHPM) adalah tidak sesuai dengan rambu-rambu yang telah ditetapkan oleh Mahkamah dalam putusan perkara Nomor 021/PUU-IV/ 2006 tanggal 22 Februari 2007, dan telah melanggar hak konstitusional para Pemohon sehingga dalil-dalil para Pemohon dalam perkara Nomor 126/ PUUVII/ 2009 beralasan".
}

Pasal 53 (4) UU Nomor 20 Tahun 2003. Tentang hal ini, MK berpendapat:

Oleh karena itu, seharusnya pendirian BHPP atau BHPPD tidak cukup dilakukan hanya dengan Peraturan Pemerintah, atau Peraturan Gubernur/Bupati/Walikota karena menyangkut pelepasan harta pemerintah atau pemerintah daerah yang memerlukan persetujuan DPR atau DPRD. Pasal 45 ayat (2) Undang-Undang Nomor 1 Tahun 2004 tentang Perbendaharaan Negara (UU 1/2004) menyatakan, "Pemindahtanganan barang milik negara/ daerah dilakukan dengan cara dijual, dipertukarkan, dihibahkan, atau disertakan sebagai modal Pemerintah setelah mendapat persetujuan DPR/DPRD". J elas pembuat UU BHP tidak mempertimbangkan keberadaan UU 1/2004, hal demikian terbukti UU BHP tidak mencantumkan UU 1/2004 dalam konsiderans mengingat padahal pembentukan BHP sebagaimana dimaksud oleh UU BHP mensyaratkan adanya harta yang dipisahkan dari pendiri dalam hal BHPP dan BHPPD adalah Pemerintah dan Pemerintah Daerah sebagaimana disebutkan dalam Pasal 37 ayat (1) UU BHP kekayaan awal BHPP, BHPPD, dan BHPM berasal dari kekayaan pendiri yang dipisahkan. ${ }^{17}$

Di luar UU Nomor 20 Tahun 2003, pengaturan badan hukum terdapat dalam KUH Perdata (BW) Pasal 1653 dan 1654. Dalam dua pasal tersebut, dijelaskan 4 (empat) jenis badan hukum (zadelijke lichaamen) yaitu, Pertama, Badan hukum yang diadakan (didirikan) oleh kekuasaan umum; Kedua, Badan hukum yang diakui oleh kekuasaan umum; Ketiga, Badan hukum yang diperkenankan, Keempat, Badan hukum yang didirikan untuk maksud tujuan tertentu.

Menurut de heersende' leer untuk membedakan mana yang badan hukum public dan mana yang badan hukum privat dapat dilihat dari (1) cara pembentukannya dan (2) peruntukkannya. J ika untuk kepentingan umum maka jelas merupakan badan hukum publik sedangkan untuk perseorangan maka jelas merupakan badan hukum privat.

\footnotetext{
${ }^{17}$ Putusan MK Nomor 11-14-21-126 dan 136/ PUU-VII/ 2009 tanggal 31 Maret 2010, hlm. 392.
} 
Terkait BHP yang diatur dalam UU Sisdiknas dan Putusan MK, maka BHP jelas merupakan badan hukum publik dimana peran Negara untuk menjalankan proses organisasi BHP Universitas sangat "mutlak". Peran warga Negara dalam membantu pelaksanaan BHP versi baru tersebut tidaklah mutlak, apabila individu warga Negara berkehendak ikut serta maka perannya tersebut diperbolehkan.

Sesungguhnya, MK sudah memberikan solusi hukum atas bentuk "badan hukum pendidikan" sebagaimana disebut dalam Pasal 53 (1) UU Nomor 20 Tahun 2003. Hal ini dapat dibaca dalam Putusan MK Nomor 11-14-21-126 dan 136/ PUU-VII/ 2009:

UU Sisdiknas bukanlah nama dan bentuk badan hukum tertentu, melainkan sebutan dari fungsi penyelenggara pendidikan yang berarti bahwa suatu lembaga pendidikan harus dikelola oleh suatu badan hukum. Adapun bentuk badan hukum itu dapat bermacam-macam sesuai dengan bentuk-bentuk yang dikenal dalam peraturan perundang-undangan, misalnya; yayasan, perkumpulan, perserikatan, badan wakaf, dan sebagainya.

MK membenarkan bahwa Badan hukum pendidikan dapat dijalankan dengan prinsip nirlaba, disamping itu, MK dalam putusannya juga mengakui bahwa tidak semua prinsip BHPP dan BHPPD yang sudah diterapkan dalam UU Nomor 19 Tahun 2009 bertentangan dengan UUD 1945. hal ini dapat dibaca dalam putusan $\mathrm{MK}$;

Menimbang bahwa meskipun keberadaan BHPP dan BHPPD sebagaimana dimaksud oleh UU BHP bertentangan dengan UUD 1945, namun tidak semua prinsip yang diterapkan dalam BHPP dan BHPPD bertentangan dengan UUD 1945. Adanya ketentuan bahwa penyelenggaraan pendidikan harus menerapkan prinsip nirlaba dalam pengelolaan pendidikan adalah benar dan tidak bertentangan dengan UUD 1945. Meskipun demikian, prinsip nirlaba itu tidak hanya dapat diterapkan di dalam BHP, tetapi dapat diterapkan pula dalam bentuk-bentuk badan hukum penyelenggara pendidikan yang lain. ${ }^{18}$

\footnotetext{
18 Putusan MK Nomor 11-14-21-126 dan 136/ PUU-VII/ 2009 tanggal 31 Maret 2010, hlm. 400.
}

Prinsip-prinsip dan bentuk-bentuk dari "badan hukum pendidikan" sesuai yang dijelaskan dan ditafsirkan MK dalam Putusan MK Nomor 11-14-21-126 dan 136/PUU-VII/ 2009 sesungguhnya menjadi bahan hukum utama guna merumuskan Rancangan Undang-undang (RUU) yang baru yang mengatur masalah Badan Hukum Pendidikan sebagai amanat Pasal 51 (1) junto Pasal 51 (4) UU 20 Tahun 2003.

\section{Penutup \\ Simpulan}

Selain merevisi beberapa Anggaran Dasar PTN/ PTS yang dibentuk berdasarkan UU Nomor 20 Tahun 2003 dan UU Nomor 9 Tahun 2009, pemerintah pusat (Presiden c.q. Mendiknas) dan Pemerintah Daerah (Gubernur, Walikota dan Bupati) harus segera mencabut seluruh peraturan perundang-undangan yang dibentuk yang mengacu kepada UU Nomor 9 Tahun 2009.

Amat penting segera disusun Undangundang Tentang Badan Hukum Pendidikan, sesuai dengan amanat Pasal 53 (1) junto Pasal 53 (4) UU Nomor 20 Tahun 2003, dengan mengacu kepada Putusan MK Nomor 11-14-21-126 dan 136/ PUU-VII/ 2009 tanggal 31 Maret 2010 dan Putusan Nomor 021/PUUIV/ 2006 pada 22 Februari 2007. Dalam dua putusan tersebut, MK telah mendefenisi makna dan batasan "Badan Hukum Pendidikan" yang konstitusional.

Belajar dari praktek pembentukkan UU di DPR, amat sulit pembahasan RUU Badan Hukum Pendidikan yang sesuai dengan rambu-rambu yang sudah diatur dalam Putusan MK Nomor 1114-21-126 dan 136/PUU-VII/ 2009 dan Putusan Nomor 021/PUUIV/ 2006 akan selesai dalam waktu 3 (tiga) bulan. Maka amat penting Pemerintahan (Presiden) mengeluarkan Peraturan Perundang-undangan Pengganti Pemerintah (Perppu).

Secara konstitusional, Perppu merupakan salah satu salah satu bentuk peraturan perundang-undangan. Eksistensinya dapat dibaca dalam Pasal 1 angka 4 UU Nomor 10 Tahun 2004 tentang Pembentukan Peraturan Perundangundangan dan Pasal 22 UUD 1945 yang menjelaskan bahwa pertama, dalam hal ihwal ke- 
gentingan yang memaksa, Presiden berhak menetapkan peraturan pemerintah sebagai pengganti UU, kedua, peraturan pemerintah itu harus mendapat persetujuan Dewan Perwakilan Rakyat dalam persidangan yang berikut, dan ketiga, jika tidak mendapat persetujuan, maka peraturan pemerintah itu harus dicabut.

Masalahnya yang timbul dalam kaitan rencana pembentukan Perppu tentang UU Badan Hukum Pendidikan, bukan pada eksistensi, namun terletak pada alasan yang dapat membenarkan kehadiran Perppu tersebut sebagai emergency law. Alasan ini menjadi amat penting karena Pasal 22 Ayat (1) UUD 1945 menghendaki kondisi atau hal inwal kegentingan yang memaksa atas rencana penerbitan Perppu.

Setidaknya terdapat beberapa pertimbangan pentingnya kehadiran Perppu tentang UU Badan Hukum Pendidikan. Pertama, Putusan MK Nomor 11-14-21-126 dan 136/ PUU-VII/ 2009 tanggal 31 Maret 2010 berimplikasi kepada banyaknya peraturan perundang-undangan yang harus dicabut dan direvisi. Pencabutan dan/ atau revisi peraturan-perundangan dimaksud, tidak saja menyangkut teknis regulasi semata, tetapi berimplikasi terhadap eksistensi badan dan organ lembaga pendidikan yang diatur di dalamnya. Baik dari status Perguruan Tinggi (PTN/PTS) maupun semua lembaga pendidikan formal dan informal yang dibentuk oleh masyarakat. Kemudian, berbagai peraturan perundang-undangan yang akan direvisi membutuhkan payung hukum yang jelas setingkat dengan UU. Dengan kata lain, adalah langkah hukum yang keliru bila Putusan MK Nomor 11-14-21126 dan 136/PUU-VII/ 2009 tanggal 31 Maret 2010 hanya ditindaklanjuti dengan beberapa Peraturn Pemerintah (PP). Bila tidak dibentuk sebuah UU Badan Hukum Pendidikan dalam waktu yang secepat-cepatnya, tidak saja persoalan hukum yang akan timbul. Namun akan menimbulkan social cost yang amat tinggi.

Kedua, dari segi prosedural pembentukan sebuah UU. Praktek ketatanegaraan membuktikan bahwa pembentukan sebuah UU memakan waktu yang cukup lama di DPR. Sulit untuk diharapkan bahwa sebuah RUU akan dapat dibentuk dan disahkan dalam waktu kurang dari
6 (enam) bulan. Sedangkan kebutuhan regulasi setingkat UU yang mengatur masalah badan hukum pendidikan sebagaimana diamanatkan Pasal 53 (1) junto Pasal 53 (4) UU Nomor 20 Tahun 2003 menjadi kebutuhan yang amat mendesak.

Dua alasan di atas menjadi pijakan konstitusional bagi Pemerintah (c.q. Presiden) untuk membentuk sebuah Perppu Badan Hukum Pendidikan yang secara substansi sesuai dengan Putusan MK Nomor 11-14-21-126 dan 136/ PUUVII/ 2009 tanggal 31 Maret 2010 dan Putusan Nomor 021/ PUUIV/ 2006 pada 22 Februari 2007.

\section{DAFTAR PUSTAKA}

Fadjar, Abdul Mukhtie. 2006. Hukum Konstitusi dan Mahkamah Konstitusi. Jakarta: Sekjen dan Kepaniteraan Mahkamah Konstitusi Rl;

Held, David. 1995. Democracy and the Global Order: From the Modern State to Cosmopolitan Governance. Standford: Stanford University Press;

Mahkamah Konstitusi. 2009. Enam Tahun Mengawal Konstitusi dan Demokrasi; Gambaran Singkat Pelaksanaan Tugas Mahkamah Konstitusi 2003-2009, Jakarta: Sekretariat Jenderal dan Kepaniteraan MK;

Marbun, S.F. "Nagara Hukum dan Kekuasaan", J urnal Hukum lus Quia lustum, Vol 4 No. 9. 2007;

Putusan Mahkamah Konstitusi Nomor 11;

Putusan Mahkamah Konstitusi Nomor 126/ PUUVII/ 2009 tanggal 31 Maret 2010;

Putusan Mahkamah Konstitusi Nomor 136/ PUUVII/ 2009 tanggal 31 Maret 2010;

Putusan Mahkamah Konstitusi Nomor 14/PUUVII/ 2009 tanggal 31 Maret 2010;

Putusan Mahkamah Konstitusi Nomor 21/PUUVII/ 2009 tanggal 31 Maret 2010;

Thalib, Abdul Rasyid. 2006. Wewenang Mahkamah Konstitusi dan Implikasinya dalam Sistem Ketatanegaraan Republik Indonesia. Bandung: Citra Adityia Bakti; 